\section{Recurrent Regeneration through Somatic Embryogenesis Reduces Yield in Cucumber}

\author{
Maciej Ladyzynski', Aleksandra Korzeniewska, and Stefan Malepszy \\ Department of Plant Genetics, Breeding and Biotechnology, Warsaw \\ Agricultural University, ul. Nowoursynowska 166, 02-787 Warsaw, Poland
}

Additional index words. Cucumis sativus, plant regeneration, somaclonal variation

\begin{abstract}
Many plant species exhibited changes in quality after regeneration in in vitro culture, both via somatic embryogenesis and shoot organogenesis (Karp, 1991). After one, two, and four regeneration cycles from callus via somatic embryogenesis, cucumber (Cucumis sativus $\mathrm{L}$.) showed genetically based morphological changes in $8.3 \%$ to $15 \%$ of $\mathrm{IR}_{1}$ families, $18.5 \%$ of $\mathrm{IIR}_{1}$ families and $42.8 \%$ of $\mathrm{IVR}_{1}$ families, respectively (Nadolska-Orczyk et al., 1989; Pląder et al., 1998). I(II, IV, V) $\mathrm{R}_{1}$ are progenies from the self-pollination of I(II, IV, V) $R_{0}$ plants which were obtained after one, two, four, and five regeneration cycles. There was a sharp fall of yield (60\% to $70 \%$ ) of $\mathrm{R}_{0}$ plants after one regeneration cycle (Malepszy et al., 1990). After four cycles a slight variation of morphological traits of $\mathrm{IVR}_{1}$ plants and a yield drop by $17 \%$ to $25 \%$ were observed (Burza et al., 1996). There are few reports on the yield of in vitro regenerated plants after recurrent regeneration. This is important for the recurrent regeneration of elite materials. In this report, we evaluated the influence five cycles of recurrent regeneration have on yield and on selected morphological traits in cucumber highly inbred (S18) line B (from field monoecious cv. Borszczagowski ) obtained in our department.
\end{abstract}

Regeneration of $\mathrm{VR}_{0}$ plants from callus tissue grown from leaf explants was carried out following the procedure of Malepszy (1988), while rooting and acclimatization of $\mathrm{VR}_{0}$ plants according to Burza and Malepszy (1995). $V_{1}$ seeds were divided into three lots and planted in three consecutive years (1997-99). The control was from the selfpollinated plants of B inbred line. Explants in the consecutive regeneration cycles came from $R_{2}$ plants growing in sterile conditions, obtained from self-pollination of $R_{1}$ plants selected from the families with no phenotypic variation.

Field plots were randomized in complete blocks with four replicates of 16 plants each.

\footnotetext{
Received for publication 13 July 2000 . Accepted for publication 6 Dec. 2000. The cost of publishing this paper was defrayed in part by the payment of page charges. Under postal regulations, this paper therefore must be hereby marked advertisement solely to indicate this fact.

${ }^{1}$ To whom requests for reprints should be addressed. E-mail address: ladyzynski@alpha.sggw.waw.pl
}

$\mathrm{VR}_{1}$ and control seedlings were planted into plastic containers of $10 \mathrm{~cm}$ in diameter filled with peat and placed in a foil tunnel. Plants were transplanted during the first 2 weeks of June. Rows were spaced $1 \mathrm{~m}$ apart and plants spaced every $40 \mathrm{~cm}$ within a row. The field was covered with black foil. Chemical fungicides were applied in compliance with Plant Protection Calendar recommendations (published every year for the area of Poland).

Eleven harvests were performed starting the second week of July and continuing into the second week of Aug. (1999) or from the third week of July to the third week of Aug. (1997, 1998). Harvested fruits were divided into marketable ( $3-4 \mathrm{~cm}$ in diameter, $6-12 \mathrm{~cm}$ in length) and nonmarketable (shapeless, yellow and with diseases). The following morphologies were measured on 16 plants in replication: main shoot length 2 weeks after the planting and after the last harvest, number of lateral shoots after the last harvest, number of days from sowing till the appearance of the first male and female flowers. These traits were selected to evaluate their possible influence on yield. The statistical analysis used the
${ }^{\mathrm{z}}$ Mean separation within columns by Tukey's test at $P \leq 0.05$.

\section{Literature Cited}

Burza, W. and S. Malepszy. 1995. Direct plant regeneration from leaf explants in cucumber (Cucumis sativus L.) is free of stable genetic variation. Plant Breed. 114:341-345. effect of simple and recurrent in vitro regeneration on cucumber inbred line under field cultivation. Horticultural Science-Kertészeti Tudomány 28(1-2):11-13, (Hungary).

Karp, A. 1991. On the current understanding of somaclonal variation. Oxford surveys of plant molecular and cell biology. Vol. 7:1-58.

Malepszy, S. 1988. Cucumber (Cucumis sativus L.) p. 277-293. In: Y.P.S Bajaj (ed.). Biotechnol-
Burza, W., S. Malepszy, and E. Rostek. 1996. The two-way classification analysis of variance along with Tukey's test for mean separation.

Flowering of $\mathrm{VR}_{1}$ plants was delayed compared to control plants (data for morphologies not shown). $\mathrm{VR}_{1}$ progeny produced male and female flowers 2 to $3 \mathrm{~d}$ later, respectively, than the controls. $\mathrm{VR}_{1}$ plants produced about one more additional lateral shoot than controls from seeds. Although statistically significant, this value is not practically different from controls. There were no vital differences in the main shoot length for both plant groups. Control plants produced $\approx 1.29$ $\mathrm{kg} \cdot \mathrm{m}^{-2}$ more fruit than $\mathrm{VR}_{1}$ plants (Table 1 ). The number of marketable fruit was reduced $\approx 0.89 \mathrm{~kg} \cdot \mathrm{m}^{-2}$ for $\mathrm{VR}_{1}$ progeny. The contribution of marketable to total yield was $\approx 63 \%$ to $64 \%$ for both groups.

There are few data on plant quality after recurrent regeneration. This work used plant material selected from the families with no visible segregation of morphological traits to arrest the accumulation of genetic changes after successive regeneration cycles. Despite strict selection, our results from 3 years of field experiments indicate that production and plant quality changed during five successive regeneration cycles. Yield reduction resembled that observed by Burza et al. (1996) after four regenerations. This would suggest a stable tendency to reduce yield by $\approx 17 \%$, but the results of Burza et al. (1996) were based on 1 year of data. In both cases, the reduction in yield was accompanied by little or no change in morphological traits relative to the control. Plader et al. (1998) observed changes in rDNA in plants whose morphology had not changed after four regeneration cycles. These results suggest that production artificial seeds via recurrent regeneration may not allow stable propagation of elite materials.

Table 1. Mean values for yield-associated traits measured over 3-year field experiments for the highly inbred cucumber line B grown from seeds from control and regenerated plants.

\begin{tabular}{|c|c|c|c|c|c|}
\hline \multirow[b]{2}{*}{ Source } & \multicolumn{2}{|c|}{ Fruit yield $\left(\mathrm{kg} \cdot \mathrm{m}^{-2}\right)$} & \multicolumn{2}{|c|}{ No. of fruit per plant } & \multirow{2}{*}{$\begin{array}{c}\text { Wt of marketable } \\
\text { fruit }(\mathrm{g})\end{array}$} \\
\hline & Total & Marketable & Total & Marketable & \\
\hline Control plants & $7.8 \mathrm{a}^{\mathrm{z}}$ & $5.0 \mathrm{a}$ & $39.4 \mathrm{a}$ & $24.8 \mathrm{a}$ & $86.7 \mathrm{a}$ \\
\hline Regenerated plants $\left(\mathrm{VR}_{1}\right)$ & $6.5 \mathrm{~b}$ & $4.1 \mathrm{~b}$ & $36.2 \mathrm{~b}$ & $21.4 \mathrm{~b}$ & $81.2 \mathrm{~b}$ \\
\hline
\end{tabular}

ogy in Agriculture and Forestry 6. Crops II. Springer-Verlag, Berlin.

Malepszy, S., S. Marciniak, and A. Nadolska-Orczyk. 1990. In vitro culture of Cucumis sativus L. IX. Yielding of regenerated plants. Gartenbauwissenschaft 55 (5):206-208.

Nadolska-Orczyk, A., S. Malepszy, and S. Bełz. 1989. Effect of recurrent in vitro culture on somaclonal variation. XIIth Eucarpia Congress in Goettingen, Vorträge für Pflanzenzüchtung 15-II, p. 26-1.

Pląder, W., S. Malepszy, W. Burza, and Z. Rusinowski. 1998. The relationship between the regeneration system and genetic variability in the cucumber (Cucumis sativus L.). Euphytica 103:9-15. 